\title{
Resistance on Market Relocation Policy (A Case Study of Jambi City)
}

\author{
Samsuddin $^{1}$, Santi Hendrayani ${ }^{2}$, Dede Sri Kartini ${ }^{3}$, M. Yusuf ${ }^{4}$ \\ \{samsudinmip@gmail.com ${ }^{1}$, santihendrayani@gmail.com² ${ }^{2}$ dede.sri.kartini@unpad.ac.id ${ }^{3}$ \\ myusuf@unja.ac.id $\left.{ }^{4}\right\}$ \\ Sekolah Tinggi Ilmu Sosial dan Ilmu Politik Nurdin Hamzah, Indonesia ${ }^{1,2}$ \\ Universitas Padjadjaran, Indonesia ${ }^{3}$ \\ Universitas Jambi, Indonesia ${ }^{4}$
}

\begin{abstract}
The traditional market contributes to the economic improvement of the community; however, its existence contradictory to the spacial plan administration. This study aims to analyze the cause of retainers' resistance to the relocation regulation of Angso Duo traditional business. The government manages it relocated to the new location; this rule leads the refusion from marketeer. This research uses a case study. The data collected through interview, depth observation, and study document. The result of the study highlights the ignorance of community participation in decisions making leads to the protest of community, and the displacement policy inflicts financial loss of society.
\end{abstract}

Keywords: Resistance, Policy, Retainers, Market.

\section{Introduction}

The traditional market has proven in giving contribution to the society economy for middle class and under class on the contrary their existence mostly defends with the city layout which use modernization approach. Commonly the existence of traditional market is considered dirty, based on the regulation city layout, the traditional market will be moved to the appropriate place and clean. The policy that city layout put in the front like this appear the resistance from trader. This cause of the new location is not strategy, rent of the stall is expensive that give effect to the amount of buyer [1][3].

It's contrary with the argument above, before that stated that the implication policy market relocation on the basis can accept by the society with the basic reasons such as to make better the environment condition, economy, transportation, law and social [4][5]. In law aspect that the relocation of the market based on the role of. This term indirectly contains the meaning that the rejection of the policy be considered the rejection of the development [6].

Based on that problems, this research will analyze the causes of individual resistance appear from the traditional Angso Duo trader. The resistance to the relocation policy has investigated by the writer based on perspective conflict that is focus on the hegemony process and resistance [3]. Pragmatic analysis form and factor caused the apparent of résistance [7][9]. That articles have given the description society respond which is organize to the market relocation policy, this research relevant is the rejection issue considered as the unorganized movement, appear natural which evolution individual characteristic become organized collective action. That's 
why this research focus on policy rejection caused by individual actors on Angso Duo traditional market at Jambi City.

The new location of Angso Duo is built by PT Eraguna Bumi Nusa (EBN). It consists of 2.688 trader which relocated to the new location base on governor's and mayor's Jambi decision. The starting of relocation since November $11^{\text {th }} 2018$ [10]. On the relocation development appear many kinds of rejection until post relocation with many arguments. Scott mention this action as the "everyday resistance" to defend of life or to keep old system [11].

\section{Research Methods}

This article use exploratory qualitative research that has purpose to quarry decision maker which is appear respond from the society [12]. Based on case study this article will analyze the appearing of the defend to the relocation policy Angso Duo traditional market. The data sourcing got from interview with the traditional traders, market department and civil service unit which is integration with the observation participant activity. Interview and observation data supported with study to many sources such as the research finding, print media and non-print media (online media).

The quarrying of the data by determine of key person, then using snowball sampling technique with asking informant who is considered has information about research object. The data analysis does by analyst interactive model data which include coding and data reduction, the data supply, drawing conclusion and verification. At the end of the discussion the writer will recommendation of the practical solve problem to the phenomena of the résistance government policy.

\section{Theoretical Framework}

Informal sector such as traditional market is one of the victim from the modern retail development which is dominate around $31 \%$ retail and the domination by 10 big companies [13]. Beside that the informal sector always be the victim of government policy and sometimes pressed on, make them depressed and lost by beautiful layout of the city [9].

Basically the purpose of the relocation is to relocate specific activity to appropriate location by considering location strategy, the supporting of accessibility, visual factor about harmony impression and beautiful so easy to attract consumer, the hierarchic of the development, the effective and efficient of the service the cheap cost of rent or sell the stall so it isn't heavy to the trader [4]

The model in making type decision top-down clearly visible meanwhile the moving of paradigm to the bottom-up also faced unpredictable [14]. That moving looks like clear with mix approach. But the mix method often become conflict which manipulative or unsuitable [15]. In harmony, the link of the power between government and the society is not parallel commonly appear the vertical contention between trades and government [16].

Resistance is collective action which is lax organize without organization to change product in their community [17]. The résistance is a defend cause of the government power in the transformation process that has big power in involve to the society [11]. As specific there are two reason in rejection: First the depend happen because injustice and suppression that can't be 
tolerated so show the brave attitude to take the risk in doing direct confrontation to hegemony of country. Second the life demands which is insurmountable [18].

Resistance is the rejection to follow the instruction, follow the regulation which is refer to someone or a group of community. Traders in an Angso Duo who refuse to disobey and not obey orders for relocation by the provincial government and city government can be seen as resistance from traders, because they do not comply with local regulations governing traders. Basically, this research looks the rising of the causes defend as the individual action which rise from personal become collective action.

\section{Results and Discussion}

\subsection{Rejection Form}

The form expression of relocation policy rejection refers to daily defend such as complaint, persuade the other to defend another trader, do the action like demonstration and stay sell the goods at the previous place. The total amount of the traders in old Angso Dua is around 2688 and the new market is around 2400 trader. That action become the collective action such as sell the good in front of mayor Jambi city office, the action defend the government policy request add the extra time to relocation till the final time the number of the trader around 200 submit the claim to the court of first lawsuit to the Jambi district court [19]. The steps of demonstration strategy is the common strategy to express their disappointed to the government policy [20]. At this phase rice the collective realized that the important oh action collective to reject of relocation policy.

\subsection{Top-Down Policy}

The policy to relocation the old of Angso Duo market to the new location basically has purpose to give the appropriate place and arrangement to the trader in doing trade activities. By relocation of Angso Duo which is expected can return the previous function of the facilities that ca not used before. It is caused the main street become to the transaction of trader and the location is dirty.

In the process the purpose to give the appropriate place doesn't followed by participatory plan as encourage the aspiration of society. The rise of the policy without public consultation process can appear respond likes rejection from the impact of the regulation [21]. The trader needs that the relocation of old Angso Duo by rearrangement that not appropriate anymore but the implication the relocation moved to new location. Even though the new location is not far from the old location but the new location more complicated because the trader must to fill all the complex and long administration process.

On policy formulation process to establishment of relocation policy do by government side. Commonly the traders don't know the effect of the relocation. The government directly set the implication with the third side. The top-down model in implication will rise the conflict [15]. The relocation of Angso Duo appear the rejection respond that individual tend.

Even the traders do not understand what the government want though the effect the trader haven't hope because the stall flat with the land. Relocation do by forced using government agency public order enforces helped by the police from Jambi city cannot be resisted because 
the among of them and complete facilities. Meanwhile the trader does not have power because the limitation of human sources and facilities and the trader must save their good.

\subsection{High Rent Cost}

Relocation from the old location to the new has the economy consequence to the trader. The trader must extra budget to rent the stall. The rent at the new location more expensive than the old place. The price of the stall size: 1,5 x2,0 is Rp.18.900.000, 2,0x2,0 is Rp.25.200.000, $3,0 \times 2,0$ is 37.800 .000 and 1,5x2,0 is Rp.20.200.000. The trader like to sell the good with the old location because it's easy to get there and also the size of the stall at the new location smaller than the old location. It's getting worse the less commitment of management in giving rent price of stall [22]. The high rent of the stall gives the consequence to making high price to sell the product. So, this case makes the buyer will move to find the other place that the location is nearer.

\subsection{The Place is Not Strategy}

The relocation is government action in order the trader from one place to another place that government prepared [9]. From the location, Angso Duo became the chosen of the trade to society of Jambi City so this sector can absorb and job vocation in the economy competition. The size of the building $3 \times 2,5=128$ (food and seasoning) Units, $2 \times 1,5=412$ Units (vegetables), $2 \times 2=168$ Units (seafood), $2 \times 2=180$ Unit (fish), $2 \times 1,5=72$ Units (fish), $3 \times 2=64$ Units Seafood), $2 \times 1,5=232$ Units (chicken meat).

The market relocation to new location has implication, the fact that the new location hasn't access as easy as the old one. The new location larger than the old one but it is far from main street. It makes the controller longer and the location vegetables and fish stall put on back so that buyer farer to the location. Parking and garage tip already paid and in the parking area the buyer must pay again. While the post of Angso Duo relocation in some place arise the new markets that that easy to get it.

The relocation rejection caused by the replacement of the traders are not appropriate and thought the new relocation improper to sell the products [23]. If compare with the old Angso Duo means that Angso Duo new more suitable to the trader. But the access and drop the goods become the reason why the new location deserted from visitor.

Based on the finding this article arguments that the rejection is not the only not strategic of new location but also the higher price the rent of the stall with the old market [7]. However, the resistance of Angso Duo context also caused by the government relocation top-down policy. The relocation can be accepted by the society because it could be environment, economy and social improvement. Therefore, the relocation of the market basically gives rise the individual or collective rejection [4].

\section{Conclusion}

Based on the aim of this research is to analyze the cause of the relocation rejection Angso Duo market. This research found that the rejection done by individual market become collective action. Taking the decision without public consultation process is the main factor of rejection appear. The reason of top-down policy with the new relocation is not strategy and the higher 
price of the stall rent. The expensive price of the stall could be one of the reasons to rejection of this policy. From this article the writer gives the recommendation that in taking decision and policy implementation should be done participative based on the government regulation which is mandate the development planning process is done with participative.

\section{References}

[1] Palupiningdiyah, "Komitmen pedagang pasar bulu kota Semarang pasca relokasi penjualan," $J$. Minamika Manaj., vol. 2, no. 2, pp. 181-193, 2011.

[2] L. Wijayanti, "Implementasi inovasi kebijakan pembangunan berkelanjutan di kota Surakarta: relokasi PKL di taman monumen Banjarsari ke pasar klitikan Notoharjo," J. Pembang. Wil. Kota, vol. 8, no. 2, pp. 126-137, 2012.

[3] D. Hermanto, B. V. Nurdin, and B. Wirawan, "Gerakan sosial pedagang kaki lima (Studi tentang hegemoni pada pedagang kaki lima di pasar Bambu Kuning kota Bandar Lampung)," Humanus, vol. X, no. 1, pp. 46-51, 2011.

[4] G. A. Atteng, J. O. Waani, R. J. Poluan, and E. D. Takumansang, "Persepsi pedagang kaki lima di pasar 45 terhadap implementasi kebijakan relokasi tempat usaha oleh pemerintah kota Manado," Sabua, vol. 5, no. 1, pp. 10-15, 2013.

[5] A. S. Widodo, S. Idayanti, D. I. Permanasari, and A. Sahri, "Kebijakan relokasi pegadang kaki lima (PKL) di kawasan kota Tegal," J. Ilmu Pemerintah. Kaji. Ilmu Pemerintah. dan Polit. Drh., vol. 1, no. 1, pp. 168-188, 2016.

[6] A. Adicahya, "Penggusuran pedagang kaki lima sebagai perbuatan melawan hukum," Justitia J. Huk., vol. 1, no. 1, pp. 61-78, 2017.

[7] L. O. Alumdin, J. Hos, and A. Upe, "Resistensi sosial pedagang di kota Kendari (Studi kasus penolakan pengembalian pedagang pasar Panjang ke pasar sentral Wua-Wua pasca relokasi)," Neo Soc., vol. 3, no. 3, pp. 534-540, 2018.

[8] S. Andreasmi and B. Utomo, "Resistensi pedagang terhadap relokasi pasar tradisional di kelurahan Mariana kecamatan Banyuasin 1 kabupaten Banyuasin," J. Swarnabhumi, vol. 3, no. 2, pp. 130-134, 2018.

[9] I. R. Husain, L. O. T. Ode, and R. S. Suraya, "Resistensi pedagang kaki lima terhadap razia Satpol PP di pasar sentral kota lama Kendari," Etnoreflika, vol. 6, no. 3, pp. 237-248, 2017.

[10] Rohmayana, "2.688 pedagang Angso Duo lama dipindah ke Angso Duo baru," Tribun Jambi, Jambi, Nov-2018.

[11] J. C. Scott, Weapons of the weak: everyday forms of resistance. New Haven and London: Yale University Press, 1985.

[12] I. Soehartono, Metode penelitian sosial, suatu teknik penelitian bidang kesejahteraan sosial dan ilmu sosial lainnya, vii. Bandung, Indonesia: Rosdakarya, 2008.

[13] S. Sutardi, "Pasar modern vs pasar tradisional: negara wajib melindungi yang lemah," Suar, Jakarta, pp. 28-31, 2011.

[14] M. Hill and P. Hupe, Implementing Public Policy Governance in Theory and in Practice. London, New Delhi: SAGE Publications, 2002.

[15] R. E. Matland, "Synthesizing the Implementation Literature : The Ambiguity-Conflict Model of Policy Implementation,” J. Public Adm. Res. Theory J-PART, vol. 5, no. 2, pp. 145-174, 1995.

[16] M. Yusuf and Syafrial, "A big battle: the state vs. indigenous people (case study in Jambi province )," J. Ilmu Sos. dan Ilmu Polit., vol. 23, no. 1, pp. 59-71, 2019.

[17] P. Sztompka, Sosiologi Perubahan Sosial (The sociology of social change). Jakarta: Prenada, 2014.

[18] Nurudin, R. K. D. Susilo, and T. Sulistyaningsih, Eds., Kebijakan Elitis Politik Indonesia. Yogyakarta: Pustaka Pelajar dan Fisip UMM, 2006.

[19] J. Sirait, "Pasca relokasi pasar Angso Duo, 200 pedagang gugat ke pengadilan," Gatra, Jambi, Jan-2019.

[20] Satriani, Juhaepa, and A. Upe, "Resistensi sosial masyarakat suku bajo (Studi kasus atas 
perlawanan masyarakat di pulau Masudu kecamatan Poleang Tenggara terhadap kebijakan resettlement ke desa Liano kecamatan Mataoleo kabupaten Bombana)," Neo Soc., vol. 3, no. 2, pp. 408-415, 2018.

[21] M. Yusuf and Z. Qodir, "Resistensi atas kebijakan pengelolaan hutan (studi pada masyarakat Orang Rimba di provinsi Jambi," J. Ilmu Pemerintah. Kebijak. Publik, vol. 1, no. 2, pp. 330-379, 2014.

[22] R. Putra, "Lagi-lagi pasar Angso Duo modern Jambi bermasalah," Radio Repulik Indonesia, Jambi, Sep-2018.

[23] O. Darmawan, "Kebijakan pemerintah provinsi DKI Jakarta terhadap relokasi pedagang kaki lima perspektif hukum dan HAM (Policy of DKI Jakarta provincial government for relocation of street vendors in perspective law and rights)," J. Penelit. Huk. Jure, vol. 16, no. 4, pp. 477-491, 2016. 